\title{
The Desirability and Feasibility of Restorative Justice
}

Victoria McGeer and Philip Pettit

\section{Introduction $^{1}$}

Restorative justice is a participatory system for determining the recompense that an acknowledged offender owes to a victim, where the participants represent a range of stakeholders in the offence. It may be implemented within a criminal justice system or within any system for dealing with offences or injustices: say, in schools or sports clubs, churches or professional organizations. It represents a stark alternative to the standard operation of the criminal justice system or of any punitive system for exacting recompense. There are clearly limits to the contexts in which it may be employed and we shall not discuss them here: that is a matter for empirically and democratically sensitive institutional design. But we hold that within the limits where it can be used, it promises to deliver very appealing results.

In most cases of restorative justice offenders have to own responsibility for their offence and agree to the use of the restorative system, although there are also cases where judges use it to provide advice on the sentence they should give to a convicted offender. We shall concentrate here on the more common arrangement. Offenders who opt for going through the system agree to enter a conference for determining recompense, where the parties may represent any of a range of stakeholders to the offence. The offender will be there with some representatives from among colleagues, friends or family. So will the victim, assuming an ability and willingness to attend, as well as representatives to speak for his or her point of view. Others from the community affected or from relevant organizations may also be invited to take part, as may experts of various sorts. And the conce itself operates under the direction of some recognized authorit 2 he conference proceeds via discussions in which everyone has a chance to get their say and the aim is to determine what the offender

1 - A version of this paper is also published in Restorative Justice: An International Journal (2015/vol. 3). 
ought to do by way of making up for harms caused by the offense. There is an upper limit on the rectificatory measure that may be decided but there is no lower limit; thus it will be at the discretion of the conference to ent for what would count as an exercise of mercy in the normal court syster She dual requirement that offenders be willing to own responsibility for their offense and that the conference involve multi-party deliberation imposes limits on where and when the restorative justice system may be employed. But it can play an important role in a variety of contexts and it can offer an instructive model for the rest of the criminal justice system, embodying ideals that we think any system ought to seek to honor. So at an we try to argue, taking our lead from a range of contemporary literature 2 ir paper is in two main parts. In the first we look at a philosophical case for welcoming restorative justice reforms, making this case on the basis of a neo-republican conception of freedom. And then in the second we argue that, despite appearances to the contrary, the reforms would fit with what psychology suggests about our evolved punitive dispositions; they are not proposals of a psychologically infeasible kind.

\section{The desirability of restorative justice}

\section{Criminal justice and freedom}

The criminal justice system is assigned many different roles in different theories, including retribution, deterrence, rehabilitation, and protection. But one common thread in all approaches is the assumption that the system is needed to defend and enhance the freedom of the members of the society: for short, its citizens. Any criminal justice system would clearly be inferior to another if the stakeholders in the system - the citizens affected - did less well in terms of freedom than they would have done under the alternative. Montesquieu ${ }^{3}$ would have agreed with using liberty as the key metric here, arguing that it is "on the liberty of the subject principally depends 2 he stakeholders in the criminal justice system are actual victims, potential victims, and offenders. In judging how well the system does by these stakeholders we assume that it should treat all of them as equal citizens, including the offenders. Recognizing the blameworthiness of offenders is

2 - See for example Heather Strang and John Braithwaite (eds.), Restorative Justive: Philosophy to Practice, Aldershot: Dartmouth-Ashgate, 2000; Gordon Bazemore and Mara Schiff, Restorative Community Justice: Repairing Harm and Transforming Communities, New York: Routledge, 2001; John Braithwaite, Restorative Justice and Responsive Regulation, New York: Oxford University Press, 2002; Albert W. Dzur, "Restorative justice and civic accountability for punishment", Polity, vol. 36, no. 1, pp. 3-22; Andreas von Hirsch, Julian Roberts, Anthony E. Bottoms, Kent Roach and Mara Schiff, (eds.), Restorative Justice and Criminal Justice: Competing or Reconcilable Paradigms?, Oxford, UK: Hart Publishing, 2003.; Gerry Johnstone, A Restorative Justice Reader: Texts, Sources, and Content, Devon: Willan Publishing, 2003; Howard Zehr and Barb Toews, Critical Issues in Restorative Justice, Monsey: Criminal Justice Publishing, 2004; Gerry Johnstone and Daniel W. Van Ness, Handbook of Restorative Justice, Taylor \& Francis, 2007; Gerry Johnstone, Restorative Justice: Ideas, Values, Debates, New York: Routledge, 2013.

3 - Montesquieu, The Spirit of Laws (1748), Berkeley, University of California Press, 1977, p. 217. 
consistent with acknowledging their equal status as citizens and prescribing penalties that do not intuitively deny them that status. While the implications of that status are bound to be indeterminate and to require democratically contestable interpretation, they certainly mean that no offender should be treated in a cruel or demeaning manner, for example, and that nould be cut off from the possibility of regaining their full civic right $\Omega$ ut how should freedom be understood, if we are to look for a criminal justice system - or for any system of rectification, including one of restorative justice - that serves the freedom of stakeholders well? We shall understand freedom in the traditional republican sense to require non-domination, in particular nondomination in those choices that each can exercise and enjoy at the same im as others: for short, those choices often designated as the basic liberties. enjoy non-domination in a choice you must not suffer arbitrary interference: roughly, intentional and voluntary interference that you do not yourself control or do not control in democratic community with other citizens ${ }^{5}$. But just contingently enjoying the absence of such arbitrary interference, say as a result of good luck, does not mean that you are free in the republican $\mathrm{Pe}$. You must enjoy such non-interference with a high degree of robustnes u must enjoy the non-interference robustly on two fronts. First, you must not enjoy it in a given choice just because you want a particular option; it must be the case that you would have enjoyed it even if you had wanted a different option instead. ${ }^{6}$ And second, you must not enjoy that non-interference just because other people are happy to let you choose as you will; it must be the case that you would have enjoyed it even if they had not been happy to give you such leeway. In other words, you must enjoy the absence of arbitrary interference in the exercise of your basic liber regardless both of what you want to do and of what others want you to d 2 is conception of freedom is best understood in contrast to the idea of freedom as non-interference: that is, freedom as actual rather than robust non-interference. Three contrasts stand out in particular. The first is that you can suffer actual interference, and lose freedom as non-interference, without suffering domination. This will happen when the interference is not arbitrary: when, for example, it is imposed under a proper democracy. By standard accounts of freedom as non-interference laws always interfere in your choices, even if they are democratically controlled to the point

\footnotetext{
4 - For an account of the connection between republican freedom and issues in criminal justice see John Braithwaite and Philip Pettit, Not Just Deserts: A Republican Theory of Criminal Justice, Oxford: Oxford University Press, 1990; Philip Pettit, "Criminalization in Republican Theory", In R. A. Duff, Lindsay Farmer, S. E. Marshall, Massimo Renzo and Victor Tadros, Criminalization: The Political Morality of Criminal Law, Oxford: Oxford University Press, 2015. And for more general discussion of the republican view see Philip Pettit, Republicanism: A Theory of Freedom and Government, Oxford: Oxford University Press, 1997; Quentin Skinner, Liberty Before Liberalism, Cambridge: Cambridge University Press, 1998; Cecile Laborde and John Maynor (eds.), Republicanism and Political Theory, Oxford, Blackwell, 2007. Philip Pettit, On the People's Terms: A Republican Theory and Model of Democracy, Cambridge: Cambridge University Press, 2012; Philip Pettit, Just Freedom: A Moral Compass for a Complex World, New York: W.W.Norton and Co 2014

5 - Philip Pettit, On the People's Terms..., op. cit.; Philip Pettit, Just Freedom..., op. cit.

6 - Isaiah Berlin, Four Essays on Liberty, Oxford: Oxford University Press, 1969.
} 
of not being arbitrary; they penalize your doing various things, although they do not actually prevent them. The theme is prominent, in the work of Jeremy Bentham, ${ }^{7}$ one of the earliest defenders of freedom as non-interference: "All coercive laws, (...) and in particular all laws creative of liberty, are, as far as they go, abrogative of liberty." The republican conception of law is quite different. Coercive laws, which are required to identify and defend your basic liberties, do not count as dominating insofar as you and your fellow citizens exercise control over the form they take. Freedom, in this sense, is not reduced by law. The theme is present in Locke, ${ }^{8}$ for example, when he writes: "where there is no law there is no freedom". And it is equally presen Kant: "a lawful constitution (...) secures everyone his freedom by laws" 2 e second contrast between freedom as non-domination and freedom as non-interference derives from the fact that non-domination requires the robust absence of arbitrary non-interference, not just its contingent absence; it requires that you enjoy non-interference regardless of what you want to do and regardless of what anyone else wants you to do. You may enjoy freedom as non-interference just because you are lucky enough to escape interference. But luck cannot give you freedom as non-domination. Suppose you are subject to a master but to one who is gentle and not disposed to interfere in your life. Even in that case you are unfree in the republican sense. You may be able to do as you wish in your choices, even able to do whatever you might wish, but that will only be because of the indulgence and permission of another, so that it is the will of the other that is in ultimate charge. Richard Price, ${ }^{10}$ an $18^{\text {th }}$ century English republican, expresses the point quite clearly when he says: individuals who are held under masters " pot be denominated free, however equitably and kindly they may be treated 20 e third contrast between freedom as non-domination and freedom as non-interference is that whereas the first requires freedom in the exercise of the basic liberties, which is a condition that each citizen can in principle enjoy at the same time as others, the second requires freedom in an undefined range of choices. Thus freedom as non-domination directs us towards the ideal of being a free person: someone who enjoys the robust absence of arbitrary interference - presumably under the public, manifest protection of the society's laws and norms - in a range of co-enjoyable choices that the laws and norms identify. In an old image, it becomes indistinguishable from the status of being able to look others in the eye without reason for fear or deference. By contrast, freedom as non-interference remains an ideal of free choice, where it is perfectly possi or some people to enjoy such freedom in far more choices than others he status associated with freedom as

\footnotetext{
7 - Jeremy Bentham, Anarchical Fallacies (1843), In John Bowring, The Works of Jeremy Bentham, vol. 2, Edinburgh: W.Tait, 1843, p. 503.

8 - John Locke, Two Treatises of Government, Cambridge: Cambridge University Press, 1960, s. 57.

9 - Immanuel Kant, Practical Philosophy (1929), tr. Mary J. Gregor, Cambridge: Cambridge University Press, 1996, p. 297.

10 - Richard Price, Political Writings, Cambridge: Cambridge University Press, 1991, p. 77.
} 
non-domination has two sides, one objective, the other inter-subjective. On the objective side, the protective laws and norms of your society ensure that you are not exposed to arbitrary interference: you are robustly secure against it. And on the inter-subjective side, the public nature of those laws and norms means that this is a matter of common awareness: everybody is aware you enjoy it, aware that everybody is aware you enjoy it, and so on. ${ }^{11}$ You must enjoy an objective and inter-subjective status that enables you, by the stiffest local criteria, to look others in the eye without a reason for fear or defere Or at least without a reason that derives from their power of interference? what follows we adopt the standpoint of the republican conception of freedom, which we think was the commonly accepted account in the grand tradition of political philosophy among authors like Polybius and Cicero in the Roman world, ${ }^{12}$ Machiavelli in the world of the Renaissance, ${ }^{13}$ and Rousseau in prerepublican France. ${ }^{14}$ Rousseau gives particularly powerful expression to his attachment to freedom as non-domination in the Second Discourse when he says: "in the relations between man and man the worse that can happen to one is to find himself at the other's discretion". ${ }^{15}$ We believe that the republican way of thinking about freedom provides solid ground for arguing in support of restorative justice. ${ }^{16}$

\section{Freedom and actual victims}

Morally if not legally, victims are the primary stakeholders in any system of criminal justice or any alternative like the system of restorative justice. And one of the main questions to be raised about such a system of rectification is, how seriously does it take the freedom of victims and how well does it do in restoring their freedom in the wake of an offense. We may assume that any crime or offence against a victim is likely to be a form of interference in that person's life, and in particular a form of interference that affects the exercise of one or a number of basic liberties. It is likely to affect the person's choices, as identified and protected in law, in for example the realm of speech or association or religion, residence, employment or ownership. The question then is how a rectificatory system could res a victim to freedom in the event of such an offensive form of interferend shall be discussing this question in light of the republican conception of freedom as non-domination. But it is worth noting in advance of that discussion that the question does not make

\footnotetext{
11 - David K. Lewis, Convention, Cambridge: Harvard University Press, 1969.

12 - Chaim Wirszubski, Libertas as a Political Ideal at Rome, Oxford: Oxford University Press, 1968.

13 - Quentin Skinner, Liberty Before Liberalism, op. cit.

14 - Jean-Fabien Spitz, La Liberté Politique, Paris, PUF, 1995.

15 - Jean-Jacques Rousseau, The Discourses and Other Early Political Writings, Victor Gourevitch (ed.), Cambridge: Cambridge University Press,1997, p. 176.

16 - John Braithwaite and Christine Parker, Restorative Justice is Republican Justice, In Gordon Bazemore and Lode Walgrave (eds.), Restorative Juvenile Justice, New York, Willow Tree Press, 1999.
} 
much sense, if freedom means freedom as non-interference. It is unclear what any system of rectification could do about restoring someone's freedom as non-interference in the wake of an offence. The restitution of something taken in an offence, or compensation for any un-restitutable harm, or reparation in a case where neither restitution nor compensation is possible, would do nothing to undo the interference actually perpetrated in the past. It could not undo in any way the fact that the pers vas the victim of such interference and was rendered to that extent unfre 2 it where freedom as non-interference leaves little or no room for the idea of restoring the freedom of a victim in wake of an offence, freedom as non-domination does allow for this possibility. From the point of view of either ideal, almost every offensive act of interference imposes an actual loss or harm, often one that might equally have come about by a natural accident: this, as in damage to your health or life, the loss of property, or the frustration of one or another plan. And while reparation, compensation or even restitution may be possible with this aspect of the offence, it is not going to mean that you didn't actually suffer interference. But from the point of view of freedom as non-domination, freedom consists in the status of someone who is equally and publicly protected by law in the range of the basic liberties. And a rectificatory system can restore you to the status of a free citizen insofar as it establishes that the offence was an unfortunate contingency and that you do still enjoy the status of someone who in general is robu protected against the arbitrary interference of others in your basic libertie hy relevant offence challenges your status or standing as someone properly and publicly protected in the domain of the basic liberties. The offender does not just happen to interfere with you in a certain manner, as if by accident. Assuming intentionality or negligence, the offender displays a disregard for the protections that we in the society had provided for you. Those protections signal a clear message of respect: that you are one of us, a person adequately and equally protected against offences of the kind you suffered. But the offender, speaking from within our ranks, communicatos a message that denies you this status, giving the lie to the public signa 2 suming that the offence means that you suffered this denial of status, how are we to restore you to the enjoyment of freedom as non-domination? We raise the question with non-fatal offences in mind, although the issue arises even in that case, with family or friends standing in for the victim. One response to the offence might be lock up or even execute the offender. But that would not silence the offender's testimony to your lack of status: your exposure to their arbitrary intrusion in your life. You might be protected against them as you might be protected against a dangerous animal. And to that extent your objective status might be secure. But you would not have enjoyed their affirmation of your status and their retraction of the message conveyed in the offence. Similar points apply with any response to the offence that consists in imposing some harsh treatment, be that a heavy fine or a form of community service. While certainly harmed by such treatment, the offender may remain hostile and even

ink that the cost paid was worth it for the pleasure of pushing you around. hese observations suggest that two things are going to be very important in 
rectifying an offense - particularly, in restoring a victim to freedom. The first is that there be an objective assurance that the victim is secure against the offender and the second that the offender give this assuran n inter-subjective form by retracting the message conveyed in the offence ose observations show why restorative justice promises to do so well by the freedom of actual victims. For the conference supported under the system is designed specifically to get the offender to recognize the harm done, and to make this manifest to the victim and to the others present by an expression of remorse or apology or something of the kind. That may not be deemed enough in itself, since words on their own are cheap. But in the well-functioning restorative conference the different sides can come to an agreement about what the offender needs to do in order to give credibility to such words and to enhance thereby the objective as well as the inter-subjective aspect of the victim's status. They may decide that the offender should help out the victim or the victim's family in some way, for example, or should contribute financially to an organization for helping victims of the sort of offense in question, or shou rform some type of community service in reparation for the harm don ere are two striking contrasts, then, between how actual victims fare under restorative justice and under more standard rectificatory processes. First, restorative justice puts the focus on the restoration of the victim's inter-subjective status via the recognition of the offender. Second, while it typically involves some form of treatment designed to give credibility to the offender's recognition of the victim, it does not resort to such treatment just as a means of achieving a deterrent or punitive effect.

\section{Freedom and potential victims}

Whenever you suffer an offense of some kind, it is very likely that others in your reference group, others who are relevantly similar to you, will suffer a setback at the same time. Their objective status as free citizens - their security against such offenders - will be put in doubt by the evidence of the offender's success in your case. And so that evidence will also contribute a negative message about their inter-subjective status. Indeed since you yo ff will count among potential victims, you will be party equally to that los his raises the question as to how we may restore potential victims to their status as free citizens in wake of a particular offence. The standard response is to think that we can achieve this insofar as the measure imposed on the specific offender is not only burdensome enough to make it credible that they will not offend again; it also teaches a general lesson for would-be offenders: that they face the prospect of similar treatment, should they offend. We should impose treatment on the offender, in other words, th deterrent in a generic way as well as being deterrent for the actual offende 2 is response clearly carries weight and it supports the earlier point that even in a restorative justice context, we should not be generally prepared to settle for just a verbal apology from an offender. But the response is not adequate on its own for it leaves a serious problem still in place. The problem is that criminal justice regulation, or any regulation with credible rectificatory intent, should ideally have a 
communicative dimension in censuring the offender. ppose that there are rules in place in any domain of behavior that impose sanctions of one kind or another on certain actions. Take as an example the rules that dictate where you can and cannot park your car in a certain city, where the sanctions attached to violations are financial fines. For all that the existence of such a system of rules requires, drivers may treat the fines as if they were fees. They may park their cars illegally in full recognition that there is a certain chance of incurring a certain fine: say, a $10 \%$ chance of having to pay a fine of $\$ 100$. And they may then think on this or that occasion, even perhaps as a general habit, that the expected cost of $\$ 10$ is a reasonable fee for the city to charge them. In a phrase, they may treat the risk they take in parking illegally as giving them an titlement to park there; they will see it as an admission cost for the behavior. hy is the deterrence response to the problem raised earlier not fully adequate? Why would it not identify a way in which we might be sure of restoring potential victims to the enjoyment of freedom as non-domination in the wake of an offence? The reason, as the analogy should make clear, is that deterrence might be provided by sanctions that offenders in general were inclined to treat merely as admission costs for committing the sanctioned offenses. And providing for deterrence in that way would not be enough on its own, in the wake of an offence agaipct you, to restore other potential victims to the enjoyment of their freedom. 2 order to enjoy freedom as non-domination, potential victims have to enjoy both the objective and inter-subjective assurance of not being exposed to the arbitrary interference of others. But the potential victims of someone who offended against you, or the potential victims of like offenders, are hardly going to be able to enjoy the required assurance, if it appears that such offenders treat the deterrent sanctions in the manner of admission costs, as opposed to appropriate expressions of societal condemnation. Suppose that there are would-be thieves or muggers in the neighborhood, for example, who are likely to interfere in anyone's life whenever the costs look right. Neither you nor any potential victim is going to be able to look them in the eye without reason for fear or deference. More generally, neither you nor any potential victim is going to e ${ }^{\circ}$ the objective or inter-subjective status associated with republican freedom hat would give potential victims the assurance required in the wake of the offence against you? Well, suppose that the laws in place expressed condemnation of the offence, as well as holding out the prospect of deterrent costs. Suppose that the offender accepted that the offence was condemnable and displayed due remorse or apology or whatever. And suppose that the offender proved willing to accept the deterrent costs imposed, thereby giving credibility to the expression of regret. In that case, it seems fairly clear that potential victims might well feel that their status as un-dominated citizens was fully restored to them, despite the offence committed against you. The very condemnation imposed on the offender would mark the protected status

17 - Joel Feinberg, "The expressive function of punishment", The Monist, vol. 49, 1965, pp. 397-423; R. A. Duff, Punishment, Communication, and Community, Oxford: Oxford University Press, 2001. 
that they enjoy, in common with you d now we can see why the restorative justice system promises to do so well by potential victims as well as by actual. For under a restorative system where the conference led to the desired result, potential victims would enjoy precisely the effect triggered by the fulfillment of those suppositions. They could look your offender in the eye - as the offender, ideally, could look them in the eye - without reason for fear or deference. And, insofar as restorative justice became the rule, they could look any potential offender in the eye with the same assurance. They would continue to enjoy freedom as non-domination in the wake of the offence in the same degree to which they enjoyed it before.

\section{Freedom and offenders}

For all we have said so far, the restorative justice system might seem to promise great benefits in freedom as non-domination for victims and potential victims but might not do so well on that count by offent themselves. But we think that the system also holds promise for offenden ne of the great dangers of the criminal justice system in terms of freedom - one of the great dangers, indeed, of any rectificatory system - is that it can put offenders under the more or less arbitrary power of police, prosecutors, courts and prisons. Ideally the power of such officials and organizations should be controlled, ultimately democratically controlled, so that there is little or no room for the agents in the system to have voluntary discretion in how they interfere with offenders or those charged with an offence. But in practice the range of discretion is likely to be enormous. The literature on police violence, prosec $\sigma^{\mathrm{al}}$ abuse, biased courts and prison abuse underlines the message powerfull 2 he issue of arbitrariness that concerns us here arises in the way in which the offender or defendant is judged and sentenced. And the question is how the treatment of those admitting or charged with an offence is likely to vary as between a restorative justice conference and a regular criminal court. Or as between a restorative justice conference and the back room in which a deal is made between the prosecution and the defending counsel, often in a context of thr $\rightarrow$ here the charge is likely to be increased unless the defendant pleads guilty thout going into detail about the familiar problems that arise in the court rooms and the back rooms of the justice system, it should be clear that the prospects for the offender's undominated status are much brighter in the restorative justice conference. The main attractions of the conference in this context are the fact that it is participatory, with each of the stakeholders, including those on the offender's side, having their say; it is restrictive of the discretion of powerful individuals in looking for consensus across all the parties involved; and it offers the opportunity for negotiation as those on the offender's side can make proposals for what the offender should do to make up fo offense and those on the victim's can counter with suggested revision actual offender can complain about being called to account for their action; it would have been clear to them that any offence would open up that possibility. But being called to account in a restorative justice conference means being treated as someone equal in status freedom to others. The way the conference 
proceeds and the kind of measures eventually proposed may not be to the offender's taste. But the manner in which the discussion is organized and the final decision is taken does not involve arbitrarily intruding on the offender. On the contrary, the whole procedure is premised on the assumption that this is an exchange between civic equals, not an arrangement that allows the innocent to pursue payback against the guilty. From the offender's point of view, it testifies to their un-dominated status and ought to serve to reinforce their sense of that status. On this front, as in respect of actual and potential victims, the restorative justice system is an institutional means of promoting freedom as non-domination.

\section{The feasibility of restorative justice}

\section{The feasibility question}

We have argued for the desirability of restorative justice on grounds related to the ideal of freedom, especially as interpreted in republican terms. Restorative justice in the sense defended does not retreat from requiring the offender to undertake some burdensome measures. And it does not retreat from requiring this on the grounds of their actually being guilty of the offence, rather than on grounds of its being socially beneficial to impose those measures. Restorative justice is defended here on the consequentialist ground that it promises to enhance the freedom of stakel prs. But in these respects it is in line with the thinking of many retributivist though the line taken is friendly in that respect to retributivist thinking, however, it is premised on the assumption that human beings are not generally brute retributivists, as it is sometimes put. They do not respond to perceived offenses with a brute inclination to punish the offender, regardless of whether or not punishment promises to be for the best. But the view that human beings are brute retributivists of this kind has received some support in the recent psychological literature. And so in mak 8 a case for restorative justice, we need to examine the claims of that view. human beings are brutely retributive, then they will be frustrated unless offenders receive harsh treatment, whatever the costs of that treatment. And in that case there is little or no hope for restorative justice policy. Restorative conferences will be a sham or they will degenerate into a fight between the offender, and perhaps the offender's representatives, and those on the side of the victim. The ideal of the restorative conference that promotes the freedom as nondomination of stakeholders will simply be infeasible: 1 asant dream but one that is doomed by the realities of human psycholog order to bolster the case made for the desirability of restorative justice, we need to be able to argue also for its feasibility. That argument has to turn on the psychological findings in the area and in this second section of the paper we look at the current evidence on the question of whether human beings are brute retributivists. We

18 - It is quite consistent with the rejection of brute retributivism that societies where the members are brutely retributive - these might be other primates, not human beings - are less violent and more cooperative. 
think that the evidence suggests that human beings have a complex psychology, involving some retributivist elements, but that this psychology is quite consistent with a belief in the potential efficacy of a system of restorative justice.

\section{The case against feasibility}

One influential line of research in support of the brute retributivist thesis comes from behavioural economics. ${ }^{19}$ Using a variety of economic games, researchers in the area have found that participants are disposed to punish other players when they perceive those players to have acted unfairly; they are prepared to deduct money from the rewards of offenders or impose some other material sanctions. Importantly, the participants in the games explored are ready to inflict such punishment, even when it costly for them to do so, and when there is no balancing compensation: players are not in a position to benefit in future encounters from having punished in the present. This phenomenon of "altruistic punishment", as it is sometimes called, seemingly provides evidence of robustly retributive psychological tastes. ${ }^{20}$ Indeed, a more dramatic illustration of this phenomenon is found in the apparent willingness of participants to inflict costly punishm offenders even when they are just witnesses, not victims, of the offence. 2 his behavior grounded, as it may seem to be, in a brutely retributive intuition that punishing wrongdoers is intrinsically valuable? Or is it motivated by a consequentialist assumption to the effect that punishing offenders generally has beneficial consequences, say in reducing the number of offences? The evidence in recent studies in social psychology is somewhat ambiguous. Some researchers have found that that when subjects are asked why offenders should be punished, they appear to endorse consequentialist as well as retributive justifications. ${ }^{22}$ However, when people are asked to assign punishment, they do so proportionally to how serious they rate the offense, displaying a relative indifference to the deterrent or incapacitating value of the punishment. Some psychologists have concluded that

19 - For a review, see Michael E. McCullough, Robert Kurzban and Benjamin A. Tabak, "Cognitive systems for revenge and forgiveness", Behavioral and Brain Sciences, vol. 36, no. 1, 2013, pp. 1-15.

20 - Ernst Fehr, Urs Fischbacher and Simon Gachter, "Strong reciprocity, human cooperation, and the enforcement of social norms", Human Nature, vol. 13, no. 1, 2002, pp. 1-25; Ernst Fehr and Simon Gachter, "Altruistic punishment in humans", Nature, vol. 415, no. 6868, 2002, p. 137.

21 - Ernst Fehr and Urs Fischbacher, "Evolution and human behavior", vol. 25, no. 2, 2004, pp. 63-87; But see Eric J. Pedersen, Robert Kurzban and Mischael E. McCullough, "Do humans really punish altruistically? A closer look". Proceeding of the Royal Society of London B: Biological Sciences, 2013, p. 280

22 - Robert M. McFatter, "Sentencing strategies and justice: Effects of punishment philosophy on sentencing decisions", Journal of Personality and Social Psychology, vol. 36, no. 12, 1978, p. 1490; "Purposes of punishment: Effects of utilities of criminal sanctions on perceived appropriateness", Journal of Applied Psychology, vol. 67, no. 3, 1982, p. 255; John M. Darley, "Just punishments: Research on retributional justice", In Michael Ross and Dale T. Miller (eds.), The Justice Motive In Everyday Life, New York: Cambridge University Press, 2002, pp. 314-333; Uli Orth, "Punishment goals of crime victims", Law and Human Behavior, vol. 27, no. 2, 2003, pp. 173-186; Kevin M. Carlsmith, "On justifying punishment: The discrepancy between words and actions", Social Justice Research, vol. 21, no. 2, 2008, pp. 119-137. 
factors linked to retributive theories - perhaps the just deserts, as they are seen, of the offender - matter more for the magnitude of the punishment imposed than any considerations about its deterrent or other utility. ${ }^{23}$ Thus it seems that even if subjects talk the talk of consequentialist justification, they walk the walk of brute retributivism. ${ }^{24}$

\section{The case for feasibility}

But these results do not unequivocally support the idea that human beings are brute retributivists. Nadelhoffer and colleagues ${ }^{25}$ caution against concluding too quickly that peoples" punishment decisions reflect a fundamental commitment to retributivist principles. As they point out, the proximal explanation for peoples" punishment decisions may be that they follow a certain "decision procedure", where they follow that procedure because it promises to produce a result that is justified in other terms. Thus, people may judge that punishment is of value only insofar as it deters crime: only insofar as it satisfies a consequentialist "criterion of right". But they may think that in order to achieve this result, punishment must be delivered on the basis of a non-consequentialist "decisi ule": always punish according to the perceived just deserts of the offender $\_$is proposal raises the question as to whether there are any studies that explore people's underlying punishment goals: their views as to what ultimately justifies the imposition of punishment, providing a "criterion of its rightness"? The issue is important, because if people are guided by a suitable criterion of rightness, that shows that they are not brute retributivists after all. Resolving this issue is difficult, alas, not least because people themselves may be unclear about, or even ignorant of, their underlying goals. But one line of research addresses the issue indirectly: namely, research on when punishment brings satisfaction to $\mathrm{p} \rightarrow$ e, leading to psychological closure and a sense of restored justice. dies in this area have delivered interesting results. Carlsmith and

23 - On its deterrent effect, see Kevin M. Carlsmith and John M. Darley, "Psychological aspects of retributive justice", In M. P. Zanna (ed.), Advances in Experimental Social Psychology, San Diego: Elsevier, vol. 40, 2008, pp. 193-236.

24 - Kevin M. Carlsmith, "The roles of retribution and utility in determining punishment", Journal of Experimental Social Psychology, vol. 42, no. 4, 2006, pp. 437-451; John M. Darley, "Morality in the law: The psychological foundations of citizens' desires to punish transgressions", Annual Review of Law and Social Science, vol. 5, 2009, pp. 1-23; Eyal Aharoni and Alan J. Fridlund, "Punishment without reason: Isolating retribution in lay punishment of criminal offenders", Psychology, Public Policy, and Law, vol. 18, no. 4, 2012, p. 599.

25 - Thomas S. Nadelhoffer et al., "Folk retributivism and the communication confound", Economics and Philosophy, vol. 29, no. 2, 2013, pp. 235-261.

26 - The findings here are limited to the context of $2^{\text {nd }}$-party punishment, i.e. where victims themselves punish offenders (e.g. in the context of responding to defectors in a cooperative enterprise); but they are powerfully suggestive nonetheless. Critical indices of satisfaction include a sense of restored justice (everyone got what they deserved) and of psychological closure. For a fuller account see Friederike Funk, Victoria McGeer and Mario Gollwitzer, "Get the Message: Punishment Is Satisfying If the Transgressor Responds to Its Communicative Intent", Personality and social psychology bulletin, vol. 40, no. 8, 2014, pp. 986-997. 
colleagues ${ }^{27}$ made the following very surprising finding. People are strongly motivated to punish offenders, being even ready to impose it at a cost to themselves, but when they do so they anticipate wrongly that they will feel satisfied by delivering the punishment. ${ }^{28}$ As a matter of fact the punishers in the study did not experience the satisfaction they anticipated. Indeed, Carlsmith and colleagues found those who punished were actually less satisfied than those who did not punish, perhaps because of being more in to dwell on the action of the wrongdoer: being unable to let it go. study did not include any feedback from offenders (for instance, as to whether they understood they were being punished for their behaviour), and so did not investigate how such feedback might affect the punishers themselves. But other studies have indicated that this variable is critical. The findings indicate that punishers do derive satisfaction from punishing offenders but only when there is specific feedback from the offenders that recognizes and acknowledges the victim's intent to punish. These studies suggest that people care about conveying the message that they are punishing offenders when they impose a punitive cost, and care in particular that the offenders a $m$ get that message, and show that they understand the punishers' intent. finding fits nicely with the line argued earlier in the paper about the expressive or communicative aspect of rectification in general. It serves to rebut the view that people are brute retributivists for whom all that matters is that they give offenders their just deserts. People may be relatively retributive in exacting punishment - they may do so without explicit consideration of the benefit of the practice - but it appears they are nonetheless deeply concerned th ensuring the delivery of an effectively reprobative message to offenders. e saw earlier that it is possible that people operate with a retributive decision procedure but do so because of embracing a distinct criterion of right: a justification for following it that is not itself retributive; it does not rule, for example, that it is right to punish the guilty, regardless of other effects. What we have now seen is evidence that they may work with a criterion of right according to which imposing punishment makes sense just insofar as

27 - Kevin M. Carlsmith, Timothy D. Wilson and Daniel T. Gilbert, "The paradoxical consequences of revenge", Journal of Personality and Social Psychology, vol. 95, no. 6, 2008, pp. 1316-1324.

28 - The finding that participants anticipate satisfaction from imposing a sanction on a defecting partner, even if it is costly to them, is in line with a neuroimaging study that found activation in the dorsal striatum, part of a neural network that plays a critical role in predicting future rewards as a result of goal directed-behaviour and decision-making (de Quervain, Fischbacher, Treyer, Schellhammer, Schnyder, Buck and Fehr, de Quervain, D. J. F., U. Fischbacher, Valerie Treyer, Melanie Schellhammer, Ulrich Schnyder, Alfred Buck and Ernst Fehr, "The neural basis of altruistic punishment", Science, vol. 305, no. 5688, 2004, pp. 1254-1258.

29 - The non-punishers in this contrast condition were people who did not have the option of punishing the offender. $90 \%$ of people in this condition reported they would punish if given the opportunity and also predicted they would feel satisfied by such punishment.

30 - Mario Gollwitzer and Markus Denzler, "What makes revenge sweet: Seeing the offender suffer or delivering a message?", Journal of Experimental Social Psychology, vol. 45, no. 4, 2009. pp. 840-844; Mario Gollwitzer, Milena Meder and Manfred Schmitt, "What gives victims satisfaction when they seek revenge?", European Journal of Social Psychology, vol. 41, no. 3, 2011. pp. 364-374. 
it delivers a message of reprobation to the offender, ideally a message that the offender acknowledges. This in itself suggests, then, that people are not brutely retributive and that there is no deep problem of feasibility for the system of restorative justice. On the contrary, that system is built around the idea of conveying to offenders the harm associated with the offence and (8) thing them to recognize this and to express and communicate remorse. 2 is lesson is supported by a follow-up study, involving one of the authors of the current piece. ${ }^{31}$ This investigation sought to identify the specific aspects of offender feedback that make punishment satisfying for victims. The hypothesis explored was that even though it may be important for people that offenders get the message that punishment is meant to convey, even more important is that offenders internalize the message: that is, they respond to it with a change in their moral attitude. Are people mainly interested in "transformative" rather than retributive justice? Is their primary concern, not in the del of punishment as such, but in getting offenders to alter their attitude e study suggested that this is indeed people's primary concern. The investigators looked at how far punishment delivered victim satisfaction under three conditions. In one, victims were unaware of whether the offender recognized the intention to punish; in another, they learned that the offender had recognized this but did not have any change of attitude; and in a third, they learned that apart from recognizing the intent to punish, the offender felt remorse and formed an intention to amend future behaviour. The finding of the study was that victims derived significantly more satisfaction in the third scenario and that the difference forst two did not have any effect on their level of satisfaction. gical results strongly suggest that the restorative justice proposals for which we argued in the first section of the paper are well fitted to the psychology of human beings and satisfy an important feasibility condition. We think that there are powerful normative reasons, based in the republican conception of freedom, for why the system of restorative justice should be implemented in the widest possible range of contexts. And we hold that there is nothing about human psychology that suggests that those proposals are out of line with the dispositions deeply ingrained in our nature. ${ }^{33}$

31 - Friederike Funk, Victoria McGeer and Mario Gollwitzer, "Get the Message: Punishment Is Satisfying If the Transgressor Responds to Its Communicative Intent", op. cit.

32 - It is worth noting in addition that there was no difference between those two conditions and a condition in which victims were not able to inflict any punishment at all. This strongly suggests that punishing is not satisfying in itself; punishing is only satisfying if it has the right sorts of consequences, i.e., as we argue here, the consequence of reproving and thereby transforming the offender's attitudes.

33 - We are indebted to the very helpful comments received from John Braithwaite and from two anonymous referees. 


\section{AUTEURS}

Victoria McGeer (vmcgeerlaprinceton.edu) est professeure dans le département de philosophie de l'Université de Princeton, chercheure associée au University Center for Human Values (Princeton) et au College of Arts and Social Sciences de l'Australian National University. Ses recherches portent sur la psychologie morale, le développement des capacités intellectuelles et morales des individus, la nature des explications en psychologie naive et la métaphysique de l'esprit. Elle est en train de travailler sur deux lives: Mind and Time. A developmental approach to human intentionality (sous contrat pour MIT Press) et Autism and Self Regutation.

Philip Pettit (ppettitaprinceton.edu) est professeur de la chaire L.S. Rockefeller of Politics and Human Values de l'Université de Princeton; il est également Distinguished University Professor of Philosophy à l'Australian National University. Il est spécialiste de la théorie morale et politique, de la philosophie de l'esprit et il a contribué de manière considérable au domaine de la métaphysique politique et sociale. Avec John Braithwaite, il a publié Not Just Deserts : A Republican Theory of Criminal Justice (Oxford University Press, 1990). Ses livres les plus récents sont Just Freedom: A Moral Compass for a Complex World IW.W. Norton, NY, 2014) et The Robust Demands of the Good: Ethics with Attachment, Good, and Respect (Oxford University Press, 2015). Hest en train de travailler sur deux autres livres: The Birth of Ethies lox ord University Presstet on Speaking Terms. Morality and its Place in Nature (Wiley Blackwell).

\section{ABSTRACT}

\section{The Desirability and Feasibility of Restorative Justice}

This article defends two main arguments. The first examines the philosophical grounds for welcoming restorative justice reforms of the penal institution, drawing on a neo-republican conception of freedom. The second argument is that, despite appearances to the contrary, these reforms would fit with what psychology suggests about our morally evolved punitive dispositions. They are not, therefore, reform proposals of a psychologically infeasible kind.

\section{RÉSUMÉ}

\section{La désirabilité et la faisabilité de la justice restaurative}

Cet article met en avant deux arguments. Le premier est une justification philosophique pour l'introduction de réformes pénales qui reposent sur l'idée de justice restaurative. On avance cet argument sur la base d'une conception néo-républicaine de la liberté. Le second argument est que, contrairement aux apparences, ces réformes sont compatibles avec ce que les recherches en psychologie tendent à montrer au sujet de nos dispositions pénales moralement évoluées. Les réformes restauratives ne sont pas, par conséquent, des propositions psychologiquement irréalisables. 
